\title{
総合論文
}

\section{全シアン及びシアン化物分析におけるシアン化水素の生成と 全シアン分析前処理法の改良}

\author{
野々村 誠 ${ }^{1,2}$
}

\begin{abstract}
シアン化合物は有毒物質であることから，環境及び排水中の全シアンは厳しく規制されている．環境及び 排水中の全シアンの分析は，工場排水試験方法（JIS K 0102）に基づいて行われているが，この方法で分析 したとき，シアン化合物を使用していない工場及び事業所の排水や廃棄物から全シアンが検出される事例が 多数報告されている．本稿では，著者らが既に報告したプリント基板めっき工場，ノーシアン亜鉛めっき工 場，カラー写真処理廃液，現像所排水，熱硬化性塗料，アルミニウム合金溶融廃棄物からのシアン化水素 （HCN）生成事例と, 最近明らかになったアルカリ固定による室温でのシアン化物イオン生成, 重油燃焼排 ガス洗浄液及び石炭火力発電所排水からの HCN 生成事例を紹介し，その生成原因について述べた。 また， JIS の全シアン分析の前処理法の経緯と問題点について述べ，その改良と HCN を生成しないシアン化合物か らの HCN の分離方法を提案した.
\end{abstract}

\section{1 はじめに}

昭和 30 年代 $\sim 40$ 年代にシアン化合物（シアン化物イオ ン及びシアノ錯体などの総称，以下，シアンという）が河 川に流出した事故等により，魚のへい死や浄水場で取水を 停止するなどの事件が多発した．そのため，昭和 46 年に施 行された水質污濁防止法では, 工場からのシアンの排出は 厳しく規制され，シアンの環境基準は全シアン（ $\mathrm{pH} 2$ 以 下で発生するシアン化水素）として,「検出されないこ と」, 排出基準は $\left\lceil 1 \mathrm{mg} / \mathrm{L}\right.$ 以下」と定められている ${ }^{1)}$. こ れらの全シアンの分析は, 工場排水試験方法（JIS K 0102, 以下 JIS という）で行われている2.

水質污濁防止法の制定後, 多くの工場では, シアンの使 用を止め, シアンを使用しない原料や製法への転換が行わ れた．例えば，めっき工場では，シアン化带鉛めっき浴か らシアンを使用しないジンケートめっき浴や酸性亜鉛アン モニウムめっき浴に, 金属熱処理工場では, シアン窒化処 理からアンモニア窒化処理へ転換されてきた。また，写真 工業では, ヘキサシアノ鉄 (III) 酸カリウムの使用を止め, p-フェニレンジアミン系化合物を主成分とするカラー写真 用処理液が用いられるようになってきた。しかし，シアン を使用していない工場や事業所の排水及び廃棄物からシア ンが検出されたり ${ }^{3) \sim 8)}$, 大学や研究所から排出される複雑

\footnotetext{
${ }^{1}$ 環境技術評価研究所 : 341-0044 埼玉県三郷市戸ヶ崎 2954 番 地 1 クレストフォルム水元公園 107 号室

2 地方独立行政法人東京都立産業技術研究センター研究開発部第 二部：115-8586 東京都北区西が丘 3-13-10
}

な組成の廃水からもシアンが検出されている ${ }^{9)}$.

シアンが検出される原因としては，工場の製造工程や廃 棄物の処理工程で生成する場合と, 公定分析法に定められ たアルカリ固定や全シアンを分析するための前処理工程で 生成する場合がある ${ }^{6)}$.

本稿では，シアンを使用していない工場の排水や廃棄物 からシアンが検出される原因と, JIS で定められた全シア ン分析方法の問題点を明かにし，分析法の改良を目的とし て著者らがこれまでに報告した事例を中心に報告する．更 に，イオンクロマトグラフ法による新たなシアン化合物の 分析方法についても紹介する.

\section{2 全シアン分析の前処理法の経緯と問題点}

環境中，特に水や排水中のシアンの分析方法に関して は，多くの報告がある ${ }^{10) 11)}$ 。このうち，全シアンの分析方 法は, 各種の公定法で規定されており ${ }^{2) 12) 13)}$, また, その解 説が報告されている ${ }^{14) 15)}$ ，わが国では，環境基準や排水基 準の全シアン分析の前処理は, JIS の 38.1.2 で規定された 方法で行われている ${ }^{2)}$. ここでは, JIS の全シアン分析の前 処理法の経緯と問題点について述べる.

\section{$2 \cdot 1$ 全シアン分析の前処理法の経緯}

JIS 法の全シアンの分析では,「試料にリン酸を加えて pH 2 以下にし, エチレンジアミン四酢酸二水素二ナトリ ウム（EDTA）を加えて加熱蒸留し, 発生したシアン化水 素（HCN）を水酸化ナトリウム溶液に捕集する」という 前処理が行われている. 全シアン分析方法の前処理操作を 


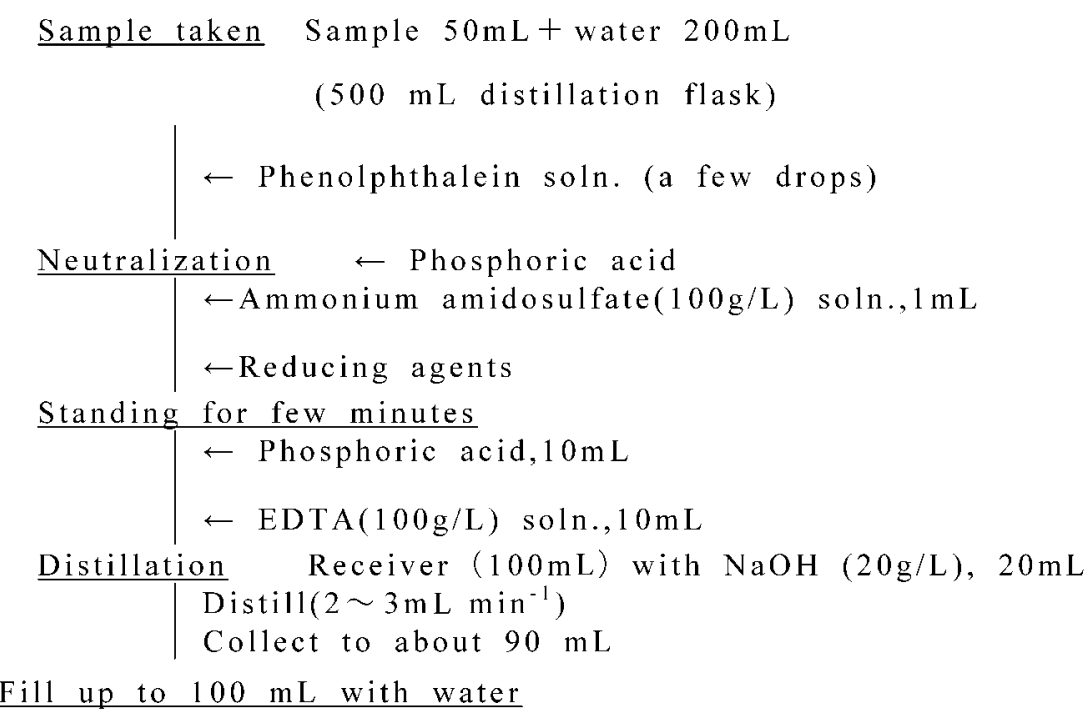

Fig. 1 Distillation procedure of total cyanide by $\mathrm{JIS}^{22)}$

Fig. 1 に示す ${ }^{2}$.

1964 年に初めて制定されたJIS ${ }^{16)}$ の全シアンの前処理は, リン酸と EDTA を添加して加熱蒸留する方法であり, 基本 的に Fig. 1 と同じである.また，この前処理は， Kruse 及 び Mellon らの方法を採用したものである ${ }^{17)}$.

JIS の全シアンの分析にEDTA を添加した理由は明らか でないが，1970 年までのシアンの規制は遊離シアンで $2 \mathrm{mg} / \mathrm{L}$ であったことから，金属イオンをマスキングする ためにEDTA を添加したのではないかと考えられる.

1971 年に改正された JIS ${ }^{18)}$ は, 1964 年とほとんど同じで あるが,「重金属を含まない排水の場合は, EDTA 溶液の添 加を省略してもよい」という注（134）が記載されてい た.

1981 年に改正された JIS ${ }^{19)}$ では, この注（134）がなくな り, 試料にEDTAを添加して全シアンの分析を行うように なった。これは, 1971 年に環境基準や排水基準が全シアン として規制されたことによるためと考えられる.また，こ の JIS 法では, 前処理操作で, 試料中の亜硝酸イオンを分 解するためにアミド硫酸アンモニウム溶液を添加すること が新たに規定された。

還元剤は, 1964 年 ${ }^{16)}, 1971$ 年 ${ }^{18)}$ の JIS 法で規定されてい た亜硫酸ナトリウム溶液が削除され, 塩化ヒドロキシルア ンモニウム溶液又は亜ヒ酸ナトリウム溶液を使用するよう に変更された。

1986 年に改正された $\mathrm{JIS}^{20)}$ は, 1981 年とほとんど同じで あるが，還元剤は，塩化ヒドロキシルアンモニウム溶液が 削除され，アスコルビン酸溶液と亜ヒ酸ナトリウム溶液に 変更された.

1993 年に改正された $\mathrm{JIS}^{21)}$ は, 1986 年とほとんど同じで あるが,「アミド硫酸アンモニウムは, 亜硝酸イオンの妨害 を除くためである. 特殊な試料では, 覀硝酸イオン以外に
も EDTA との反応で HCN を生成し，アミド硫酸アンモニ ウムを添加してもその妨害を除けないものもある。 また, EDTA 以外にも類似の反応をする有機物もある.」という 注（9）が設けられた ${ }^{21 ）}$.

1998 年に改正された JIS ${ }^{22)}$ の内容は, 1993 年の JIS と同 じである.

2008 年 3 月に改正された JIS ${ }^{2)}$ では, 注（8）の中に,「添 加した EDTA が関与すると考えられる場合は, EDTA 溶液 の添加を除いて 1）から 7）の操作を行う.」という文章が 追加された.

\section{$2 \cdot 2$ 全シアン分析の前処理法の問題点}

JIS 法による全シアン分析の前処理法の問題点は次のよ うにまとめることができる。

1）全シアンの前処理では, リン酸酸性（pH 2 以下）で EDTA を添加するが, 各種金属シアノ錯体の分解性及び EDTAの添加効果が明らかでない

2）排水中に含まれる亜硝酸イオンが EDTA と反応して $\mathrm{HCN}$ を生成する事例がある.

3）試料中の亜硝酸イオンはアミド硫酸アンモニウム溶 液を用いる分解により EDTA との反応による HCN の生成 を防止できるが, 加熱蒸留中に窒素酸化物が生成する場合 には，アミド硫酸アンモニウム溶液を加えても HCN が生 成する。

4）全シアンを分析する場合，酸化性物質の還元方法及 び最適な還元剤が明らかでない.

5）全シアンの前処理で, 加熱蒸留中に HCN を生成する EDTA 以外の有機化合物及び亜硝酸イオン以外の窒素化合 物の影響や種類が明らかでない. 
Table 1 Effect of adding agents on the distillation of metal cyanocomplexes ${ }^{28)}$

\begin{tabular}{ccccc}
\hline \multicolumn{2}{c}{ Metal cyanocomplexes } & \multicolumn{3}{c}{ Average recovery, \% ${ }^{\mathrm{a})}$} \\
Species & $\mathrm{CN}^{-} / \mu \mathrm{g}$ & $\mathrm{EDTA}^{\mathrm{b})}$ & $\mathrm{MgCl}_{2}{ }^{\mathrm{c})}$ & $\mathrm{CuSO}_{4}+\mathrm{SnCl}_{2}{ }^{\mathrm{d})}$ \\
\hline $\mathrm{Ni}(\mathrm{CN})_{4}{ }^{2-}$ & 100.4 & 98.5 & 98.2 & 92.0 \\
$\mathrm{Fe}(\mathrm{CN})_{6}{ }^{{ }^{-}}$ & 100.1 & 97.9 & 98.5 & 96.8 \\
$\mathrm{Fe}(\mathrm{CN})_{6}{ }^{-}$ & 100.1 & 96.3 & 97.2 & 97.1 \\
$\mathrm{Au}(\mathrm{CN})_{2}{ }^{-}$ & 100.2 & 11.1 & 53.2 & 55.7 \\
$\mathrm{Au}(\mathrm{CN})_{4}{ }^{-}$ & 100.6 & 7.7 & 28.7 & 72.9 \\
$\mathrm{Co}(\mathrm{CN})_{6}{ }^{3-}$ & 100.1 & 2.6 & 5.6 & 4.0 \\
\hline
\end{tabular}

a) Three samples at each concentration. b) Recommended amount in JIS method.

c) Recommended amount in Standard Methods. d) Recommended amount in ISO method.

\section{$2 \cdot 3$ EDTA の添加効果}

全シアンの前処理で添加するEDTAの効果について, 既 に報告されている結果をまとめてみる.

Kruse らは, 一定濃度（1～50 mg/L）の $\mathrm{CN}^{-}$溶液に一 定濃度 $(50 \sim 100 \mathrm{mg} / \mathrm{L})$ の金属イオン（鉄, コバルト, ニッケル, カドミウム, クロムなど）を加え, 試料溶液 135 $\mathrm{mL}$ に対し $85 \%$ リン酸 $35 \mathrm{~mL}$ を加えてシロップ状になる まで加熱蒸留すると, 銅とコバルト以外は, EDTA を添加 しなくてもほほ $100 \% \mathrm{CN}^{-}$が回収されたが, 10\% EDTAを $10 \mathrm{~mL}$ 添加すると, 銅からはほぼ $100 \%$, コバルトからは 約 $90 \% \mathrm{CN}^{-}$が回収されたと報告している ${ }^{17)}$.すなわち, Kruse らの報告は, 金属シアノ錯体からの HCNの回収率を 調べたものではなく, 強酸性で加熱蒸留したときに $\mathrm{CN}^{-}$溶 液から HCNを回収率するときの金属イオンの影響と, EDTAの添加効果について調べたものである.

中村らは, 難分解性の金属シアノ錯体を JIS 法の条件で 蒸留したときの $\mathrm{CN}^{-}$の回収率を調べた結果, ヘキサシアノ 鉄(II)酸カリウム, ヘキサシアノ鉄(III)酸カリウムの場合 は，EDTAを添加しなくてもほほ $100 \%$ 回収されたと報告 している. 一方, ペンタシアノニトロシル鉄 (III)酸ナトリ ウム, ヘキサシアノコバルト (III)酸カリウム, テトラシア ノ金(III)酸カリウムの場合は, EDTAの添加の有無にかか わらず，低い回収率であったと報告している．EDTA は難 分解性のコバルト (III) シアノ錯体などの分解に効果はな く, Kruse らの報告と同様に, この錯体の分解はリン酸が シロップ状に濃縮されたときに著しく進むと報告してい $ろ^{23)}$.

水上は, ヘキサシアノ鉄 $(\mathrm{II})$ 酸塩及びヘキサシアノ鉄 $(\mathrm{III})$ 酸塩を多量に含む試料の場合には, 1971 年の JIS 法 ${ }^{18)}$ では 全シアンは十分に回収されないが, EDTAの添加量を増や すと全シアンの回収率は増加したと報告している ${ }^{24)}$. ま た, これらの錯体を多量に含む試料の場合は, 1971 年（13 版）の米国の Standard Methods（SM 法）の前処理条件を 一部修正した方法を適用して 3 時間以上蒸留すると全シア ンの回収率は増加したと報告している ${ }^{24)}$.

典水らは, $\mathrm{CN}^{-}$とて $0.5 \mathrm{mg} / \mathrm{L}$ を含む各種金属シアノ
錯体溶液に EDTA を加えずに硫酸酸性でJIS 法 $^{18)}$ の加熱蒸 留装置を用いて, 全シアンの回収率を調べた結果, 17 種類 の試料の内, 14 種類は定量的に回収され, 回収率が十分で ない試料は, ヘキサシアノ鉄 (II) 酸イオンに亜鉛イオン, 銅イオンが共存した場合及びへキサシアノ鉄(III) 酸イオ ンに銅イオンが共存した場合の 3 種類であった。この結 果, 銅, ニッケル, カドミウム, 亜鉛などのシアノ錯体は, EDTA を添加しなくても $\mathrm{pH} 2$ 以下の加熱蒸留で, 全シア ンは定量的に回収されたと報告している ${ }^{25)}$. 全シアンの回 収率が不十分であった上記の 3 種類については, EDTAを 添加することにより全シアンが回収されたと報告してい る. そのため, これらの 3 種類が排水中に存在することは まれであるけれども，これらが共存することを想定して EDTA を添加しておくことが無難であると報告してい る ${ }^{25)}$ 。また, 山田らは, 難分解性シアンの場合には, EDTA の添加量を増加させると定量的に全シアンとして回収され ると報告している ${ }^{9)}$.

小倉らは, 難分解性金属シアノ錯体の全シアンの加熱蒸 留における EDTA 添加の効果について詳細に報告してい $ろ^{26) 27)}$.

金属シアノ錯体から全シアンを回収するためのEDTAの 働きとしては, シアノ錯体から $\mathrm{CN}^{-}$を解離させること, 共 存する金属イオンをマスキングしてへキサシアノ鉄 (II) 酸 亜鉛などの難溶性塩の生成を防ぐことであるとしている. しかし, ヘキサシアノ鉄 (II)酸イオンやへキサシアノ鉄 (III) 酸イオンまでの解離定数を持つシアノ錯体ならば酸を加え て蒸留するだけで $\mathrm{CN}^{-}$が解離し, EDTA 添加の必要性は認 められないとしている。 また, EDTAの添加量を増やすと 難溶性塩からの全シアンの回収率が増加するとの報告もあ るが, EDTA が HCN 生成の炭素源となることから, EDTA の添加量を増やすことは好ましくないとしている ${ }^{26) 27)}$.

著者らは, 1981 年の JIS 法 $^{19)}$ で定められているリン酸と EDTAを添加, 1985 年（16版）の SM 法で定められている塩 化マグネシウムと硫酸を添加及び International Organization for Standardization（ISO 法 $)^{13)}$ で定められている硫酸銅 (II) 溶液, 塩化スズ $(\mathrm{II})$, 塩酸を添加して, JIS 法の加熱蒸留装 
Table 2 Effect of reducing agents on the distillation of samples ${ }^{28)}$

\begin{tabular}{|c|c|c|c|c|c|}
\hline \multicolumn{2}{|c|}{ Samples } & \multirow{2}{*}{$\mathrm{NH}_{2} \mathrm{SO}_{3} \mathrm{NH}_{4} / \mathrm{g}$} & \multicolumn{2}{|c|}{ Reducing agent } & \multirow{2}{*}{$\begin{array}{c}\text { HCN formed } \\
\mu \mathrm{g}\end{array}$} \\
\hline Species & Amounts/g & & Species & Amount/g & \\
\hline \multirow[t]{6}{*}{$\mathrm{NaNO}_{2}$} & 0.1 & & $\mathrm{C}_{6} \mathrm{H}_{8} \mathrm{O}_{6}$ & 0.1 & $16.4^{\mathrm{b})}$ \\
\hline & 0.5 & & $\mathrm{C}_{6} \mathrm{H}_{8} \mathrm{O}_{6}$ & 0.1 & $54.4^{\mathrm{b})}$ \\
\hline & 0.1 & 0.3 & $\mathrm{C}_{6} \mathrm{H}_{8} \mathrm{O}_{6}$ & 0.1 & 6.8 \\
\hline & 0.5 & 1.5 & $\mathrm{C}_{6} \mathrm{H}_{8} \mathrm{O}_{6}$ & 0.1 & 6.0 \\
\hline & 0.1 & & $\mathrm{SnCl}_{2}$ & 1.0 & $0.0^{\mathrm{b})}$ \\
\hline & 0.5 & & $\mathrm{SnCl}_{2}$ & 1.0 & $0.0^{\mathrm{b})}$ \\
\hline \multirow[t]{4}{*}{$\mathrm{NH}_{3} \mathrm{OHCl}$} & 0.1 & & $\mathrm{C}_{6} \mathrm{H}_{8} \mathrm{O}_{6}$ & 0.1 & 79.0 \\
\hline & 0.5 & & $\mathrm{C}_{6} \mathrm{H}_{8} \mathrm{O}_{6}$ & 0.1 & 116. \\
\hline & 0.1 & & $\mathrm{SnCl}_{2}$ & 1.0 & 0.0 \\
\hline & 0.5 & & $\mathrm{SnCl}_{2}$ & 1.0 & 0.0 \\
\hline \multirow[t]{4}{*}{$\mathrm{N}_{2} \mathrm{H}_{6} 2 \mathrm{Cl}$} & 0.1 & & $\mathrm{C}_{6} \mathrm{H}_{8} \mathrm{O}_{6}$ & 0.1 & 0.0 \\
\hline & 0.5 & & $\mathrm{C}_{6} \mathrm{H}_{8} \mathrm{O}_{6}$ & 0.1 & 0.0 \\
\hline & 0.1 & & $\mathrm{SnCl}_{2}$ & 1.0 & 0.0 \\
\hline & 0.5 & & $\mathrm{SnCl}_{2}$ & 1.0 & 0.0 \\
\hline
\end{tabular}

a) in $100 \mathrm{~mL}$. Blank value was subtracted. b) $\mathrm{NO}_{2}{ }^{-}$was detected.

置を用いて難分解性の金属シアノ錯体 6 種類からの $\mathrm{CN}^{-}$の 回収率を調べた ${ }^{28)}{ }^{29)}$. その結果を Table 1 に示す.

硫酸銅 $(\mathrm{II})$ 溶液, 塩化スズ (II) 及び塩化マグネシウム を使用した時, $\mathrm{Ni}(\mathrm{CN})_{4}{ }^{2-}, \mathrm{Fe}(\mathrm{CN})_{6}{ }^{4-}$ 及び $\mathrm{Fe}(\mathrm{CN})_{6}{ }^{3-}$ から の $\mathrm{CN}^{-}$の回収率は, EDTA を用いたときとほとんど同じで あった. $\mathrm{Au}(\mathrm{CN})_{2}{ }^{-}, \mathrm{Au}(\mathrm{CN})_{4}{ }^{-}$及び $\mathrm{Co}(\mathrm{CN})_{6}{ }^{3-}$ からの $\mathrm{CN}^{-}$ の回収率は, EDTAを添加しても不十分であったが, 塩化 マグネシウムあるいは硫酸銅 (II) 溶液と塩化スズ (II) を 用いると $\mathrm{CN}^{-}$の回収率は増加した ${ }^{28)}$.

\section{$\mathbf{2 \cdot 4}$ アミド硫酸アンモニウムの添加効果}

舆水らは, アミン類と亜硝酸イオン $\left(\mathrm{NO}_{2}{ }^{-}\right)$との反応 で $\mathrm{HCN}$ が生成すること, $\mathrm{NO}_{2}{ }^{-}$をアミド硫酸アンモニウム で分解することにより，HCN の生成を防ぐことができる ことを報告している ${ }^{30) 31)}$ 。これにより，1981 年に改正され たJIS 法から, 蒸留前に $10 \%$ アミド硫酸アンモニウム溶液 を添加することが規定されている ${ }^{19)}$.

しかし, その後, 加熱蒸留中にペルオキソ二硫酸イオン と塩化ヒドロキシルアンモニウムとの反応によって生成し た窒素酸化物 ${ }^{32) ~ 34)}$ 及び室温で硝酸と亜鉛や鉄との反応に よって生成した亜硝酸などの還元生成物 ${ }^{35)}$ の場合には，あ らかじめアミド硫酸アンモニウム溶液を添加しても HCN の生成を防げないことが報告された，すなわち，アミド硫 酸アンモニウムは, 試料中に存在している $\mathrm{NO}_{2}{ }^{-}$を分解で きるが, 上記のような化学反応で生じた窒素酸化物に対し ては, 効果がないことが明らかになってきた ${ }^{32) ~ 34) . ~}$

\section{$2 \cdot 5$ 還元剤の影響}

排水中に酸化剤が共存すると, 加熱蒸留中にシアンを酸 化して負の誤差を生じること, あるいはチオシアン酸イオ ンを分解して HCN を生成し正の誤差を生じることから,
あらかじめ酸化剤を還元処理することが定められている. 還元剤は，亜硫酸ナトリウム $\left(1964\right.$ 年 $^{16)}, 1971$ 年 $\left.{ }^{18)}\right)$, 塩 化ヒドロキシルアンモニウム $\left(1981\right.$ 年 $\left.{ }^{19)}\right)$, 覀ヒ酸ナトリ ウム $\left(1981\right.$ 年 $^{19)}, 1986$ 年 ${ }^{20)}, 1993$ 年 $^{21)}, 1998$ 年 ${ }^{22)}, 2008$ 年 $\left.{ }^{2)}\right)$, アスコルビン酸 $\left(1986\right.$ 年 $^{20)}, 1993$ 年 ${ }^{21)}, 1998$ 年 ${ }^{22)}$, 2008 年 $\left.^{2)}\right)$ などに変わり, また, ISO 法では塩化スズ (II $)^{13)}$ などが用いられてきた. しかし，全シアンの加熱蒸留は $\mathrm{pH} 2$ 以下で行うために, 亜硫酸ナトリウムで還元すると 二酸化硫黄が発生し, 吸収液中で亜硫酸イオンとなり, $\mathrm{CN}^{-}$の発色を妨害する。塩化ヒドロキシルアンモニウム は, ペルオキソ二硫酸塩と EDTA が共存すると, 加熱蒸留 時に HCN を生成する ${ }^{32) ~ 34)}$ 。また, 亜ヒ酸は, 有毒物質で あるヒ素を含んだ廃液の処分が問題となる。

そこで，最適な還元片を選定するために，全シアンの分 析における還元剤の影響を調べた ${ }^{28) 36) 37)}$. 結果を Table 2 に示す.

この結果, JIS 法 ${ }^{21)}$ や 1975 年（14 版）の SM 法で用いら れているアスコルビン酸は，亜硝酸ナトリウムあるいは塩 化ヒドロキシルアンモニウムが存在すると, 全シアンの蒸 留中に HCN を生成することが明らかになった ${ }^{28)}$. しかし, あらかじめアミド硫酸アンモニウムで覀硝酸イオンを分解

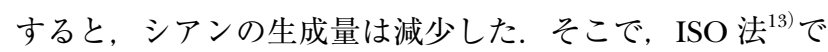
用いられている塩化スズ (II) を用い, 亜硝酸ナトリウムあ るいは塩化ヒドロキシルアンモニウムを共存させ, $\mathrm{pH} 2$ 以下で加熱蒸留すると HCNが生成しなかった ${ }^{28)}$. 更に, 二 塩化ヒドラジニウムは, アスコルビン酸あるいは塩化ス ズ (II) を共存させて加熱蒸留してもほとんど HCN が生成 しなかった。

以上の結果から, 全シアンの前処理用の還元剤として は, 塩化スズ(II) が推奨された ${ }^{28)}$. 
Table 3 Analytical results of free cyanide in the plating solution and wastewater by JIS aeration method

\begin{tabular}{|c|c|c|c|c|c|}
\hline No. & Sampling points & Main components & $\begin{array}{l}\text { Without alkaline } \\
\text { Fixation } \\
\mathrm{CN}^{-} / \mathrm{mg} \mathrm{L}^{-1}\end{array}$ & $\begin{array}{l}\text { With alkaline } \\
\text { Fixation } \\
\mathrm{CN}^{-} / \mathrm{mg} \mathrm{L}^{-1}\end{array}$ & $\mathrm{Ni} / \mathrm{mg} \mathrm{L}^{-}$ \\
\hline A & Chemical polishing bath & $\mathrm{Na}_{2} \mathrm{~S}_{2} \mathrm{O}_{8}, \mathrm{H}_{2} \mathrm{SO}_{4}$ & ND & ND & 0 \\
\hline B & Catalyst bath & $\mathrm{N}_{2} \mathrm{H}_{6} 2 \mathrm{Cl}, \mathrm{EDTA}, \mathrm{PdCl}_{2}, \mathrm{HCl}$ & ND & ND & 0 \\
\hline C & Electroless nickel plating bath & $\begin{array}{l}\mathrm{NiSO}_{4}, \mathrm{NaH}_{2} \mathrm{PO}_{2} \text {, Aminocaboxylic } \\
\text { acids, Chelating agents }\end{array}$ & ND & ND & 7350 \\
\hline (1) & Cyanide reservoir tank & Cyanide compounds & 11.8 & 28.5 & 0 \\
\hline (2) & After activated charcoal filtration & & ND & ND & 0 \\
\hline (3) & Acid reservoir tank & $\mathrm{Na}_{2} \mathrm{~S}_{2} \mathrm{O}_{8}$ & ND & ND & 3 \\
\hline (4) & After filter press & $\mathrm{Na}_{2} \mathrm{~S}_{2} \mathrm{O}_{8}$, EDTA, $\mathrm{N}_{2} \mathrm{H}_{6} 2 \mathrm{Cl}$ & ND & 0.02 & 0 \\
\hline (5) & $\begin{array}{l}\text { Electroless nickel plating reservoir } \\
\text { tank }\end{array}$ & Aminocaboxylic acids, $\mathrm{Ni}$ & 0.03 & 0.05 & 2027 \\
\hline (6) & Neutralization tank & Aminocaboxylic acids, $\mathrm{Ni}$ & ND & 0.04 & 1312 \\
\hline (7) & Mixing tank & Aminocaboxylic acids, $\mathrm{Ni}, \mathrm{Na}_{2} \mathrm{~S}_{2} \mathrm{O}_{8}$ & ND & 1.02 & 353 \\
\hline 8 & Final discharge tank & Aminocaboxylic acids, $\mathrm{Ni}, \mathrm{Na}_{2} \mathrm{~S}_{2} \mathrm{O}_{8}$ & ND & 0.81 & 304 \\
\hline (9) & Mixed solution of (4) and (6) & Aminocaboxylic acids, $\mathrm{Ni}, \mathrm{Na}_{2} \mathrm{~S}_{2} \mathrm{O}_{8}$ & ND & 1.94 & 589 \\
\hline
\end{tabular}

$\mathrm{ND}:<0.01 \mathrm{mg} / \mathrm{L}_{\text {as }} \mathrm{CN}^{-}$; A-C : Plating solutions ; (1) - (9) : Wastewater

\section{3 シアンの生成事例}

シアンを使用していない事業所の排水や産業廃棄物から シアンが検出される事例がある。これらは, シアンを含む 排水を安定に保持するための前処理や, 全シアンの加熱蒸 留中にシアンが生成する事例であり, その生成原因につい て述べる。

\section{$3 \cdot 1$ アルカリ固定による無電解ニッケルめっき排水か らのシアン化物イオンの生成 ${ }^{38)}$}

排水中のシアンを分析する際に，すぐに分析できない場 合には，排水中に水酸化ナトリウム溶液を加えて $\mathrm{pH}$ を約 12 に調整して保存する。これをアルカリ固定という。しか し, 無電解ニッケルめっき排水をアルカリ固定した後, 衛 生試験法 ${ }^{39)}$ 又はJIS 法 ${ }^{22)}$ の 38.1.1.1 (通気法) で前処理を行 うと, シアン化物イオン $\left(\mathrm{CN}^{-}\right)$が検出され, 行政の検査 機関とトラブルになった.

そこで, 無電解ニッケルめっき排水から $\mathrm{CN}^{-}$が検出され た原因を明らかにするために，工場のめっき工程，排水処 理工程を調査し, めっき液及び排水の分析を行い, その生 成原因について検討した。

この工場では, プリント基板に無電解ニッケルと無電解 金めっき（シアンを含む）を行っていた．めっき液及び排 水を JIS 法の 38.1.1.1 (通気法) で処理した後, 4-ピリジンカ ルボン酸ーピラゾロン法で $\mathrm{CN}^{-}$を分析した結果を Table 3 に示す。この結果, めっき工程の化学研磨液 (A), 触媒液 (B), 無電解ニッケルめっき液 (C) からは, 水酸化ナトリ ウム溶液を添加あるいは添加しなくても（アルカリ固定を
しても，しなくても） $\mathrm{CN}^{-}$は検出されなかった.

この工場の排水は, シアン系, 酸系及び無電解ニッケル めっき排水系の 3 系統に分かれており, Table 3 に示すよ うに 8 か所で排水を採水し, それぞれ排水 (1)〜 (8) とした. また, 排水 (4) と排水 (6) を混合したものを排水 (9) とし, 他の排水の結果と比較した。 (1)，(2) はシアン系排水，(3), (4) は酸系排水, (5), (6), (7) は無電解ニッケル系排水, 8 は最終放流槽の排水である.

シアン系排水は, アルカリ塩素法で処理した後, 活性炭 沪過を行っている. シアン系の貯槽 (1) からは, $\mathrm{CN}^{-}(11.8$ 及び $28.5 \mathrm{mg} / \mathrm{L})$ が検出されたが, 活性炭沪過後の排水 (2) からは, いずれも $\mathrm{CN}^{-}$は検出されず，シアン排水は完全に 分解処理されていた。

酸系の貯槽 (3) 及びフィルタープレス後の排水 (4) から も, いずれも $\mathrm{CN}^{-}$は検出されなかった. 無電解ニッケルめ っき排水貯槽 (5) 及び中和槽 (6) では検出せず〜 $0.05 \mathrm{mg} / \mathrm{L}$ であった。

混合槽 (7) と最終放流槽 (8) の排水では, アルカリ固定を しなければ $\mathrm{CN}^{-}$は検出されなかったが, アルカリ固定をす ると混合槽 (7) と最終放流槽 (8)の排水で, それぞれ, 1.02 及び $0.81 \mathrm{mg} / \mathrm{L}$ の $\mathrm{CN}^{-}$が検出された. なお, この工場の混 合槽 (7) と最終放流槽 (8)の排水では, それぞれ 353 及び $304 \mathrm{mg} / \mathrm{L}$ のニッケルイオンが含まれていた.

そこで, 酸系のフィルタープレス後の排水 (4) と無電解 ニッケルめっき系の中和槽 (6) の排水を同体積で混合した 溶液 (9)について調べた結果, アルカリ固定しなければ $\mathrm{CN}^{-}$は検出されなかったが，アルカリ固定すると 1.94 $\mathrm{mg} / \mathrm{L}$ の $\mathrm{CN}^{-}$が検出された. 
Table 4 Analytical results of total cyanide in the each plating process solution and wastewater by JIS distillation method ${ }^{3)}$

\begin{tabular}{llc}
\hline Sampling points & Main components & $\begin{array}{c}\text { Total cyanide/ } \\
\text { mg L }\end{array}$ \\
\hline Conditioning bath & $\mathrm{Na}_{2} \mathrm{CO}_{3}, \mathrm{Na}_{2} \mathrm{~B}_{4} \mathrm{O}_{7}$ & Not detected \\
Soft etching bath & $\mathrm{Na}_{2} \mathrm{~S}_{2} \mathrm{O}_{8}$ & 433 \\
$\begin{array}{c}\text { Soft etching rinse } \\
\text { water bath }\end{array}$ & $\mathrm{Na}_{2} \mathrm{~S}_{2} \mathrm{O}_{8}$ & 105 \\
Catalyst bath & $\mathrm{PdCl}_{2}, \mathrm{SnCl}_{2}$ & Not detected \\
$\begin{array}{c}\text { Electroless copper } \\
\text { plating bath }\end{array}$ & $\mathrm{CuSO}_{4}, \mathrm{EDTA}$, & Not detected \\
Wastewater tank & $\mathrm{HCHO}_{2} \mathrm{NaOH}$ & \\
Final effluent tank & $\mathrm{Na}_{2} \mathrm{~S}_{2} \mathrm{O}_{8}$ & 46.3 \\
\hline
\end{tabular}

Sample : $50 \mathrm{~mL} ; \mathrm{NH}_{3} \mathrm{OHCl} 0.3 \mathrm{~g}$ and EDTA $1 \mathrm{~g}$ was added.

このめっき工場排水から $\mathrm{CN}^{-}$が検出された原因は, 次の 1）〜4）のように推定される.

1）工場の排水処理工程における混合槽及び最終放流槽 の排水をアルカリ固定した際に $\mathrm{CN}^{-}$が検出された. 特に, 酸系のフィルタープレス後の排水 (4) と無電解ニッケルめ っき系の中和槽 (6) の排水の混合液に水酸化ナトリウム溶 液を加えて $\mathrm{pH} 12$ にすると $\mathrm{CN}^{-}$を生成する。

2）排水 (4) 中には化学研磨液 (A) からのペルオキソ二 硫酸カリウムと触媒液（B）からの EDTA 及び二塩化ヒド ラジニウムが含まれている. 中和槽 (6) の排水中には, 無 電解ニッケルめっき液からの高濃度のニッケルイオンとア ミノカルボン酸が含まれている.

3）(4) と (6) の排水が混合し, 水酸化ナトリウムでアル カリ固定（pH 12）した際に, ニッケルイオンの共存下で ペルオキソ二硫酸イオンが室温で自己分解し, 酸化ニッケ ルを生成する.

4）この酸化ニッケルが排水中に含まれるアミノカルボ ン酸, 特にアミノ酢酸を分解して $\mathrm{CN}^{-}$を生成する.

これらの反応は，以下のように考えられる.

$$
\begin{array}{r}
\mathrm{Ni}(\mathrm{OH})_{2}+\mathrm{S}_{2} \mathrm{O}_{8}{ }^{2-}+2 \mathrm{OH}^{-} \longrightarrow \mathrm{NiO}_{2}+2 \mathrm{SO}_{4}{ }^{2-}+2 \mathrm{H}_{2} \mathrm{O} \\
\mathrm{CH}_{2}\left(\mathrm{NH}_{2}\right) \mathrm{COOH}+\mathrm{NiO}_{2}+2 \mathrm{OH}^{-} \longrightarrow \\
\mathrm{HCN}+\mathrm{CO}_{2}+2 \mathrm{H}_{2} \mathrm{O}+\mathrm{Ni}(\mathrm{OH})_{2}
\end{array}
$$

$3 \cdot 2$ プリント基板めっき工場排水からの HCN の生成 ${ }^{3)}$ プリント基板のめっき工場では銅スルホールめっきを行 っており，シアンを使用していないにもかかわらず，この 工場排水から全シアンが検出された.

そこで, このめっき工場のめっき工程と排水処理工程を 調査し, 全シアンが検出された原因を検討した.
工場の銅スルホールめっき工程, 排水処理工程及び使用 している薬剤を調査した．工場のどの工程から全シアンが 検出されるかを明らかにするために, 前処理液, めっき液, 水洗水及び排水中の全シアンを 1981 年の JIS 法で定められ た方法で定量した ${ }^{19)}$. 結果を Table 4 に示す.

この工場ではシアンを使用していないが, ソフトエッチ ング液及び水洗水からはそれぞれ $433 \mathrm{mg} / \mathrm{L}$ 及び 105 $\mathrm{mg} / \mathrm{L}$ と高濃度の全シアンが検出された。 また, 排水貯槽 原液及び最終放流水からはそれぞれ $46.3 \mathrm{mg} / \mathrm{L}$ 及び 18.2 $\mathrm{mg} / \mathrm{L}$ の全シアンが検出された.

そこで, 工場で使用している薬剤及び全シアンの前処理 で添加する薬剤の影響を調べた。すなわち，ソフトエッチ ング剂であるペルオキソ二硫酸ナトリウム, この酸化剂を 還元するために 1981 年の JIS 法 $^{19)}$ で規定されていた塩化ヒ ドロキシルアンモニウム及びEDTAの影響を調べた。この 結果, 工場排水から全シアンが検出された原因は, 排水中 のペルオキソ二硫酸ナトリウムを塩化ヒドロキシルアンモ ニウムで還元し, EDTA を添加して pH 2 以下で加熱蒸留 を行った際に, 窒素酸化物が生成し, これが EDTA と反応 して HCN を生成するためであることを明らかにした ${ }^{32) 331}$. この排水の場合，あらかじめアミド硫酸アンモニウムを添 加しても, 窒素酸化物は分解せず, HCN の生成を防げない ことを報告した ${ }^{33)}$.

3・2・1 HCN 生成における有機化合物の影響 ${ }^{22}$ ペル オキソ二硫酸カリウム $(1 \mathrm{mmol})$, 塩化ヒドロキシルアンモ ニウム $(1 \mathrm{mmol})$ の共存下で各種の有機化合物 $(1 \mathrm{mmol})$ を加え, pH 2 以下で加熱蒸留を行い, HCN の生成量を調 べた. 結果を Table 5 及び Table 6 に示す.

この結果, カルボン酸, アミノカルボン酸, オキシカル ボン酸, アルデヒド, ケトン, 酸アミド類のようなカルボ ニル基を持つ化合物などから HCN が生成した，炭素数が 増えると HCN の生成量は減少したが, 二重結合のある化 合物からは多量の HCN が生成した。 また, アミノカルボ ン酸やオキシカルボン酸はカルボン酸よりも多量の HCN が生成した. 更に, 芳香族炭化水素, アルコール, アミン, ピリジン類のようなカルボニル基を持たない化合物から も，HCNが生成した，したがって，上記の混合系では，ほ とんどの有機化合物が HCN 生成の炭素源になることが明 らかになり, 検討した有機化合物の中では, EDTAが最も 多く（14.1\%）HCNを生成した.

3・2・2 HCN 生成における窒素化合物の影響32) ペル オキソ二硫酸カリウム $(1 \mathrm{mmol})$ 及び EDTA $(1 \mathrm{mmol})$ の共存下で, 各種の窒素化合物 $(1 \mathrm{mmol})$ を加えて $\mathrm{pH} 2$ 以下で加熱蒸留を行い, HCNの生成量を調べた，その結果 を Table 7 に示す.

ヒドロキシルアンモニウム塩及び覀硝酸ナトリウムから は多量の, 塩化ヒドラジニウムからは少量の HCN が生成 
Table 5 Formation of HCN during the distillation of samples containing various organic compounds with carbonyl group by JIS method ${ }^{\text {a), 32) }}$

\begin{tabular}{|c|c|c|c|}
\hline Compounds ( $1 \mathrm{mmol}$ ) & $\mathrm{HCN} / \mu \mathrm{mol}^{\mathrm{b})}$ & Compounds ( $1 \mathrm{mmol})$ & $\mathrm{HCN} / \mu \mathrm{mol}^{\mathrm{b})}$ \\
\hline (Carboxylic acids) & & (Oxycarboxylic acids) & \\
\hline Sodium formate & 0.0 & Hydroxylacetic acid & 25.7 \\
\hline Sodium acetate & 4.1 & Lactic acid & 4.5 \\
\hline Propionic acid & 1.9 & Sodium gluconate & 55.2 \\
\hline$n$-Hexanoic acid & 0.0 & Potassium sodium tartrate & 39.0 \\
\hline Acrylic acid & 5.5 & Citric acid & 13.2 \\
\hline Oxalic acid & 0.3 & Sodium salicylate & 1.2 \\
\hline Succinic acid & 6.5 & Gallic acid & 4.2 \\
\hline Adipic acid & 0.3 & & \\
\hline Maleic acid & 16.2 & (Aldehydes) & \\
\hline Sodium benzoate & 2.0 & Acetaldehyde & 16.3 \\
\hline \multirow[t]{2}{*}{ Potassium hydrogen phthalate } & 2.1 & Propionaldehyde & 3.1 \\
\hline & & Acrolein & 17.5 \\
\hline (Aminocarboxylic acids) & & Benzaldehyde & 1.0 \\
\hline Aminoacetic acid & 9.1 & & \\
\hline 6-Aminohexanoic acid & 0.1 & (Acetones) & \\
\hline L- $\alpha$-Alanine & 1.6 & Acetone & 5.0 \\
\hline L-Aspartic acid & 11.1 & 4-Methyl-2-pentanone & 6.5 \\
\hline L-Glutamic acid & 5.4 & Acetylacetone & 4.2 \\
\hline L-Lysine monohydrochloride & 3.3 & & \\
\hline L-Arginine monohydrochloride & 5.0 & (Acidamides) & \\
\hline Iminodiacetic acid & 13.2 & Acetamide & 4.6 \\
\hline Ethylendiaminediacetic acid & 18.3 & $N, N$-Dimethylfolmamide & 3.1 \\
\hline Nitrilotriacetic acid & 88.6 & $N, N$-Dimethylacetamide & 2.6 \\
\hline Ethylenediaminetetraacetic acid & 141.0 & Acetanilide & 0.3 \\
\hline Glycoletherdiaminetetraacetic acid & 33.1 & & \\
\hline Diethlenetriaminepentaacetic acid & 91.2 & & \\
\hline Glycolhexanediaminetetraacetic acid & 100.0 & & \\
\hline Sodium anthranilate & 0.6 & & \\
\hline
\end{tabular}

a) $\mathrm{K}_{2} \mathrm{~S}_{2} \mathrm{O}_{8} 1 \mathrm{mmol}$ and $\mathrm{NH}_{3} \mathrm{OHCl} 1 \mathrm{mmol}$ are presented. b) in $100 \mathrm{~mL}$. Blank value was subtracted.

Table 6 Formation of HCN during the distillation of samples containing various organic compounds without carbonyl group by JIS $\operatorname{method}^{\text {a), 32) }}$

\begin{tabular}{lc}
\hline Compounds $(1 \mathrm{mmol})$ & $\mathrm{HCN} / \mathrm{mmol}^{\mathrm{b})}$ \\
\hline (Aromatic hydrocarbons) & \\
Benzene & 12.2 \\
Toluene & 0.9 \\
Xylene & 1.8 \\
(Alcohls) & \\
Methanol & 5.7 \\
Ethanol & 1.1 \\
2-Propanol & 3.7 \\
(Amines) & \\
Methylamine ${ }^{\mathrm{c}}$ & 2.9 \\
$n$-Buthylamine & 0.4 \\
Ethylenediamine & 3.1 \\
1,6-Hexanediamine & 9.7 \\
Triethanolamine & 9.7 \\
(Pyridines) & \\
Pyridine & 7.8 \\
2,2'-Bipyridyl & 13.2 \\
1,10-Phenanthroline & 0.0 \\
\hline
\end{tabular}

a) $\mathrm{K}_{2} \mathrm{~S}_{2} \mathrm{O}_{8} 1 \mathrm{mmol}$ and $\mathrm{NH}_{3} \mathrm{OHCl} 1 \mathrm{mmol}$ are presented.

b) in $100 \mathrm{~mL}$. Blank value was subtracted. c) $40 \%$ solution, $0.1 \mathrm{~mL}$
Table 7 Formation of HCN during the distillation of samples containing various nitrogen compounds by JIS method ${ }^{\text {a), 32) }}$

\begin{tabular}{lc}
\hline \multicolumn{1}{c}{ Compounds $(1 \mathrm{mmol})$} & $\mathrm{HCN} / \mu \mathrm{mol}^{\mathrm{b})}$ \\
\hline (Inorganic) & \\
Hydroxylammonium hydrochloride & 141.0 \\
Hydroxylammonium sulfate & 130.0 \\
Sodium nitrite & 10.3 \\
Hydrazinium dichloride & 1.8 \\
Ammonium chloride & 0.0 \\
Potassium nitrate & 0.0 \\
Amidosulfuric acid & 0.0 \\
Ammonium amidosulfate & 0.0 \\
Sodium azide & 0.0 \\
(Organic) & 0.0 \\
Urea & 0.0 \\
Aminoacetic acid & 0.0 \\
Sulfanilamide & \\
\hline
\end{tabular}

a) $\mathrm{K}_{2} \mathrm{~S}_{2} \mathrm{O}_{8} 1 \mathrm{mmol}$ and EDTA $1 \mathrm{mmol}$ are presented. b) in $100 \mathrm{~mL}$. Blank value was subtracted. 
Table 8 Analytical results of total cyanide in the samples taken at the zincate bath shop by JIS method ${ }^{40)}$

\begin{tabular}{clrc}
\hline \multicolumn{1}{c}{ No. } & \multicolumn{1}{c}{ Sampling points } & $\mathrm{pH}$ & Total cyanide $(\mathrm{HCN}) / \mathrm{mg} \mathrm{L}^{-1}$ \\
\hline \multicolumn{2}{c}{ Plating process) } & & \\
1 & Alkaline cleaning bath & 12.1 & Not detected \\
2 & Water rinse bath & 0.2 & Not detected \\
3 & Pickle bath & 0.9 & Not detected \\
4 & Water rinse bath & 13.2 & Not detected \\
5 & Neutralization bath & 13.0 & 2.25 \\
6 & Zincate bath & 12.4 & 1.02 \\
7 & Water rinse bath & 1.0 & 0.94 \\
8 & Nitric acid dip bath & 1.8 & 0.89 \\
9 & Clear chromate bath & 1.9 & 0.64 \\
10 & Water rinse bath & 1.5 & 0.03 \\
11 & Color chromate bath & 3.3 & 0.10 \\
12 & Water rinse bath & & \\
(Wastewater treatment process) & 12.4 & 2.18 \\
$\mathrm{~A}$ & Reservoir tank (Zincate) & 11.7 & 0.54 \\
$\mathrm{~B}$ & Reservoir tank (Alkaline-Acid) & 11.1 & 0.86 \\
$\mathrm{D}$ & Sedimentation tank & 3.5 & 0.14 \\
$\mathrm{G}$ & Chromate reservoir tank & 7.6 & 0.07 \\
$\mathrm{~F}$ & Final pH adjustment tank & & \\
\hline
\end{tabular}

したが, 塩化アンモニウム, 硝酸カリウム, アミド硫酸塩 及びアジ化ナトリウムなどの無機窒素化合物からはほとん ど HCN が生成しなかった。

尿素, アミノ酢酸, スルファニルアミドなどのような有 機窒素化合物からは，ほとんど HCN が生成しなかった. したがって, 上記の混合系では, HCN の生成に関与する窒 素化合物は, ヒドロキシルアンモニウム塩, 亜硝酸塩, 塩 化ヒドラジニウム塩などに限定されると考えられた.

\section{$\mathbf{3} \cdot \mathbf{3}$ ノーシアン亜鉛めっき排水からの HCN の生成 ${ }^{40)}$}

近年, シアンを使用しないジンケート浴や酸性亜鉛めっ き浴が普及している。しかし，これらのめっき排水から全 シアンが検出された. そこで, ジンケートめっき工場排水 からの HCN の生成原因について検討した.

この工場のめっき工程, 排水処理工程を調査し, JIS 法 ${ }^{20)}$ に基づて全シアン濃度を測定した。結果を Table 8 に示 す.

この結果, めっき工程の 1（アルカリ洗浄浴）から 5 (中 和浴）では全シアンが検出されなかったが, この後のジン ケート浴, 水洗浴, 硝酸浸せき浴及びユニクロメート浴か らは, $\quad 0.89 〜 2.25 \mathrm{mg} / \mathrm{L}$ の全シアンが検出された.

排水処理工程では, ジンケート系廃液貯槽, 沈殿槽でも $0.86 \sim 2.18 \mathrm{mg} / \mathrm{L}$ の全シアンが検出された. クロメート廃 液槽及び最終 $\mathrm{pH}$ 調整槽の排水では, $0.07 〜 0.14 \mathrm{mg} / \mathrm{L}$ の 全シアンが検出された.

更に, 5 社のジンケートめっき工場の 6 種類のめっき液 を調査した結果, 液組成は, 酸化亜鉛, 水酸化ナトリウム 及びイミダゾールとエピクロロヒドリンの光沢剤からな り, めっき液中の全シアン濃度は $0.44 \sim 16.8 \mathrm{mg} / \mathrm{L}$ であっ
た.

そこで, 模擬ジンケート液 $(\mathrm{ZnO}: 12 \mathrm{~g} / \mathrm{L}, \mathrm{NaOH}$ : $110 \mathrm{~g} / \mathrm{L}$, 光沢剤 : $1 \mathrm{~mL} / \mathrm{L})$ を調製して亜鉛めっきを行 い, 一定時間ごとにめっき液中の全シアン濃度を測定し た. ジンケートめっき液中の全シアン濃度は, 電解時間に 伴って増加し, 88 時間後には $1.45 \mathrm{mg} / \mathrm{L}$ となった.

ジンケートめっき工場での HCN の生成原因は, 次のよ うに推定された。

1）ジンケートめっき液中の光沢剤はイミダゾールとエ ピクロロヒドリンからなり, 亜鉛めっき中にイミダゾール 化合物が陽極酸化によって分解し $\mathrm{CN}^{-}$を生成したものと 考えられる。 なお, 立本らは, 病院排水中に含まれるイミ ダゾールやヒダントイン化合物が次亜塩素酸ナトリウム溶 液と反応すると $\mathrm{CN}^{-}$を生成すると報告している ${ }^{41)}$.

2）亜鉛めっきはクロメート処理の前に硝酸浴に浸せき するが, このとき硝酸の一部が窒素酸化物に変わり, pH 2 以下での加熱蒸留中に EDTA と反応して HCN を生成した ものと考えられる。また，ジンケート浴以外の酸性亜鉛め っき排水からも全シアンが検出されたが $\left.{ }^{42} 43\right)$, この原因 は，2）の反応によるものであると考えられる.

なお，排水中の亜硝酸イオンをアミド硫酸アンモニウム で分解すれば，HCN は生成しないとされているが ${ }^{19)}$, 硝 酸イオンと亜鉛や鉄などが共存した場合には，アミド硫酸 アンモニウムを加えても HCN の生成を抑制できないと報 告されている ${ }^{35)}$.

\section{$3 \cdot 4$ カラー写真処理廃液からの HCN の生成 ${ }^{44) ~ 46)}$}

写真処理液中には EDTA, ジエチレングリコール，ホル ムアルデヒド, 発色現像主薬などの有機化合物と硫酸ヒド 
ロキシルアンモニウム，硝酸アンモニウムなどの窒素化合 物が含まれている。この写真処理廃液から全シアンが検出 されたので, これらの薬剤からの $\mathrm{HCN}$ の生成量を調べ, 廃液からの $\mathrm{HCN}$ の生成原因を調査した。この結果, 次の ような原因が推定された。

1）ヒドロキシルアンモニウムとホルムアルデヒドが反 応してホルムアルドキシムを生じ，これが加熱蒸留中に分 解して HCN を生成する ${ }^{47)}$. 反応は，次のようであると考 えられる。

$$
\begin{aligned}
& \mathrm{NH}_{2} \mathrm{OH}+\mathrm{HCHO} \longrightarrow \mathrm{HCH}=\mathrm{NOH}+\mathrm{H}_{2} \mathrm{O} \\
& \mathrm{HCH}=\mathrm{NOH} \longrightarrow \mathrm{HCN}+\mathrm{H}_{2} \mathrm{O}
\end{aligned}
$$

2）写真処理液中のヒドロキシルアンモニウムが空気で 酸化されて窒素酸化物を生成し, これが, 写真処理液中の アミノカルボン酸及び芳香族アミン（発色現像主薬）と反 応して HCN を生成する。

3）発色現像主薬である芳香族アミンが加熱蒸留中に過 マンガン酸カリウムによって酸化されて HCN を生成す る.

したがって，シアンを使用していない写真処理廃液から 全シアンが検出された原因は, $\mathrm{pH} 2$ 以下で加熱蒸留中に 1）から 3）の反応が複合的に起こり HCN を生成したため と考えられる.

\section{$3 \cdot 5$ 現像所排水からの HCN の生成 ${ }^{48)}$}

映画用フィルムの現像で使用する処理液では, 現在シア ンを使用していないが, この現像所の排水から全シアンが 検出された，そこで, 現像処理工程で使用している処理液 及び排水を分析し， HCN の生成原因を調查した.

現像所の排水から全シアンが検出された原因は次のよう に推定される.

1）ポジフィルム用現像処理工程の前浴及び複製フィル 厶用現像処理工程の中和液中には, 硫酸ヒドロキシルアン モニウムが含まれているために，これが $\mathrm{pH} 2$ 以下で加熱 蒸留した際に有機化合物（例えばEDTA）と反応して HCN を生成したものと考えられる.

2）硫酸ヒドロキシルアンモニウムが，パーサルブリー チ液中のペルオキソ二硫酸ナトリウム及び各種处理液中の 有機化合物と反応して HCN を生成したものと考えられ る.

3）硫酸ヒドロキシルアンモニウムが安定液中のホルム アルデヒドと反応してホルムアルドキシムを作り, 加熱蒸 留の際に分解してHCN を生成したものと考えられる.

この結果, 現像所排水からの $\mathrm{HCN}$ の生成反応は, プリ ント基板めっき工場及び写真処理廃液からの $\mathrm{HCN}$ の生成 反応と同じであると考えられる。

\section{$3 \cdot 6$ 熱硬化型塗料及び原料からの HCN の生成 ${ }^{49) 50)}$}

ブロックイソシアネートの熱硬化型塗料には, 従来アル コール系（ブチルアルコール：BA），アミン系（ジイソブ チルアミン：DIBA）のブロック剤が使われてきたが，近 年省エネルギーの塗料として, 従来のものよりも低温で硬 化するオキシム系のブロック剤が普及している。しかし， オキシム系ブロックイソシアネートの電着塗料の排水を分 析した際に全シアンが検出された，そこで，その原因を明 らかにするために, 各種のブロックイソシアネートの塗料 原料及びその混合物からの $\mathrm{HCN}$ の生成量を調べ, その生 成原因を調查した.

塗料原料及びその混合物にリン酸を加えて $\mathrm{pH} 2$ 以下で 加熱蒸留した時の HCN の生成量を Table 9 に示す ${ }^{49)}$.

イソシアネート（ヘキサメチレンジイソシアネート： HMDI，イソフォロンジイソシアネート：IPDI，トルオー ルジイソシアネート：TDI）単独では HCN をほとんど生 成しない。ブロック郕のオキシム（メチルエチルケトオキ シム：MEKO, アセトンオキシム：AO, シクロへキサノン オキシム：CyHO）からは極微量の HCN が生成したが, ISO 法で測定すると JIS 法及びSM 法よりも多量のシアン 化水素が生成した.

イソシアネートとブロック剂を混合したオキシム系のブ ロックイソシアネート (HMDI-MEKO, IPDI-MEKO, IPDI-AO, IPDI-CyHO, TDI-MEKO）からは多量の HCN が生成した。この $\mathrm{HCN}$ は, $0.1 \mathrm{~mol} / \mathrm{L}$ 硝酸銀溶液に吸収 し, AgCN としてX線回折法で確認した。一方, アルコー ル系（IPDI-BA）及びアミン系（IPDI-DIBA）のブロッ クイソシアネートからは HCN がほとんど生成しないか, 生成しても極微量であった。

市販の塗料について HCN の生成量を調べた結果，オキ シム系のブロックイソシアネート (IPDI-MEKO, MDIMEKO）からは HCN が生成したが, それ以外の塗料から はほとんど生成しなかった。

Table 9 の結果から，オキシム系のブロックイソシアネ 一トから $\mathrm{HCN}$ が生成した原因は, $\mathrm{pH} 2$ 以下で加熱蒸留し た際にオキシムがヒドロキシルアンモニウムとケトンに分 解し, 共存する他の薬剤と反応して HCN が生成したため と推定される。 また，ヒドロキシルアンモニウムが加熱蒸 留中に窒素酸化物を生成し, 共存する他の薬剤と反応して HCN を生成することも考えられる ${ }^{49)}$.

な押，著者らは，オキシムブロックイソシアネートと関 連する有機化合物からの HCN の生成機構をついて検討 し, ベックマン転移によって生成することを報告した ${ }^{50)}$.

\section{$3 \cdot 7$ 重油燃焼排ガス洗浄廃液からの HCN の生成 ${ }^{51}$}

重油は, ボイラー, 火力発電等の燃料として使われてい るが, この燃焼排ガス中には窒素酸化物や硫黄酸化物が含 
Table 9 Formation of HCN during the distillation of paint materials and oxime blocked isocyanates by JIS method ${ }^{49}$

\begin{tabular}{|c|c|c|c|c|}
\hline \multicolumn{2}{|c|}{ Samples } & \multirow{2}{*}{ Taken/g } & \multirow{2}{*}{$\begin{array}{c}\text { Total cyanide }(\mathrm{HCN}) / \mu \mathrm{g} \\
\text { JIS }^{1)}\end{array}$} & \multirow{2}{*}{ X-Ray Diffraction } \\
\hline Isocyanate & Oxime & & & \\
\hline \multicolumn{5}{|c|}{ (Paint materials) } \\
\hline HMDI & & 1.0 & $<0.5$ & \\
\hline IPDI & & 1.0 & 0.9 & \\
\hline \multirow[t]{4}{*}{ TDI } & & 1.0 & $<0.5$ & \\
\hline & MEKO & $1.0^{2)}$ & 0.6 & \\
\hline & $\mathrm{AO}$ & $1.0^{2)}$ & 0.9 & \\
\hline & CyHO & $1.0^{2)}$ & 1.0 & \\
\hline \multicolumn{5}{|c|}{ (Oxime blocked isocyanates) } \\
\hline HMDI-MEI & & $1.0^{2)}$ & 301. & Detected \\
\hline IPDI-MEKC & & $1.0^{2)}$ & 294. & Detected \\
\hline IPDI-AO & & $1.0^{2)}$ & 124. & Detected \\
\hline IPDI-CyHO & & $1.0^{2)}$ & 129. & \\
\hline TDI-MEKO & & $1.0^{2)}$ & 78.3 & \\
\hline IPDI-BA & & $1.0^{2)}$ & 1.1 & Not Detected \\
\hline IPDI-DIBA & & $1.0^{2)}$ & 0.6 & Not Detected \\
\hline
\end{tabular}

1) in $100 \mathrm{~mL}$; 2) Dissolved in methyl alcohol ; HMDI : Hexamethylenediisocyanate ; IPDI : Isophoronediisocyanate ; TDI : Toluoldiisocyanate ; MEKO : Methylethylketoneoxime ; AO : Acetoneoxime ; $\mathrm{CyHO}$ : Cyclohexanoneoxime ; BA : Buthylalcohol ; DIBA : Diisobutylamine

まれるため，アルカリ溶液で吸収して除外処理をしてい る.しかし, この廃液を 1998 年の JIS 法 ${ }^{22)}$ で分析すると全 シアンが検出された.

この廃液から全シアンが検出された原因は, 吸収液中に 含まれる 5 価バナジウムとヒドロキシルアミドトリス硫酸 イオン及び全シアンの前処理で添加するEDTAが, pH 2 以 下で加熱蒸留した際に HCN を生成するためであると報告 している ${ }^{51)}$. また, HCN の炭素源は添加した EDTAのメ チレン基, 窒素源はヒドロキシルアミドトリス硫酸イオン であると考察している。

\section{$3 \cdot 8$ 石炭燃焼排ガス洗浄液からの HCN の生成 ${ }^{52}$}

石炭火力発電所の排水を 1998 年の JIS 法で測定すると全 シアンが検出されると報告している ${ }^{52)}$.

石炭火力発電所の多くは, 石灰-石膏法による湿式排煙脱 硫法を採用し, 排ガス中の $\mathrm{SO}_{2}$ と $\mathrm{NO}_{2}$ を石灰石スラリーに 吸収させて除去している。これらの成分は, 吸収液中では, $\mathrm{SO}_{3}{ }^{2-}, \mathrm{NO}_{2}{ }^{-}, \mathrm{NO}_{3}{ }^{-}$として存在し, $\mathrm{SO}_{3}{ }^{2-}$ と $\mathrm{NO}_{2}{ }^{-}$が反応 してヒドロキシルアミンジスルホン酸塩 $\left\{\mathrm{N}(\mathrm{OH})\left(\mathrm{SO}_{3}\right)_{2}{ }^{2-}\right.$ : HADS と略記\}を生成する. HADS は, 更に $\mathrm{SO}_{3}{ }^{2-}$ と反応 してヒドロキシルアミントリスルホン酸（硫酸）塩 $\left\{\mathrm{SO}_{3} \mathrm{ON}(\mathrm{OH})\left(\mathrm{SO}_{3}\right)_{2}{ }^{3-}\right.$ : HATS と略記 $\}$ を生成する ${ }^{52)}$. し たがって，脱硫吸収液及び脱硫排水には，HADS や HATS 等の NS 化合物（窒素と硫黄を含有する化合物の総称）が 存在する.

そこで, 火力発電所の実排水に HATS を 0 ～ $2 \mathrm{mmol} / \mathrm{L}$ の範囲で添加し, EDTA を添加あるいはEDTA を添加しな いで全シアン濃度を測定した ${ }^{52)}$.

この結果, EDTA を添加し, HATS を添加せずに測定し
たときの全シアン濃度は, $0.3 \mathrm{mg} / \mathrm{L}$ であったが, HATS の 添加量を増加させると全シアン濃度も増加し, HATSを

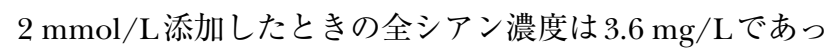
た.一方， EDTA を添加せず，HATS も添加しなければ全 シアン濃度は定量下限以下であり, HATSを $0.5 〜 2$ $\mathrm{mmol} / \mathrm{L}$ 添加すると $0.05 \sim 0.07 \mathrm{mg} / \mathrm{L}$ であった.

このことから, HATS あるいはHATS の分解生成物と EDTA が反応して HCN を生成することが示唆された。 ま た, 火力発電所排水中の全シアン分析において, EDTA を 添加しなければ HATS 等の NS 化合物からの HCN の生成 を防ぐことができると報告している ${ }^{52)}$.

なお, 久保らは, 軽質油燃焼排ガス洗浄液をイオンクロ マトグラフ-質量分析計で分析した結果, この排水中に HADS が存在することを明らかにし, pH 2 以下で加熱蒸留 すると EDTA と反応して HCN が生成すると報告してい $ろ^{53)}$.

\section{$3 \cdot 9$ アルミニウム合金溶融廃棄物からの $\mathrm{CN}^{-}$の検出 ${ }^{54) 55)}$}

アルミニウム合金の溶融時に, 脱ガス, アルミニウムの 酸化皮膜の除去, 酸化や水素ガスの吸収を防止するために フッ化物や塩化物を含むフラックスが使用されている。 し かし, これらのフラックスは, 作業中に塩素やフッ素ガス などを発生し作業環境が悪いため, 低公害用として窒素ガ スを吹き込む処理法が普及している，また，アルミニウム 合金溶融後の廃棄物（ドロス）は，廃棄する際に有害物質 の溶出試験が行われるが, その際に, この溶出液から $\mathrm{CN}^{-}$ が検出された。 そこで, この廃棄物中の $\mathrm{CN}^{-}$の溶出量を調 へ，その検出原因について調査した.

アルミニウム合金溶融廃棄物は 5 社の 11 種類について 
Table 10 Analytical results of total cyanide in the solution eluted from aluminum drosses with water ${ }^{54)}$

\begin{tabular}{|c|c|c|c|c|}
\hline Sample No. & Aluminum alloy & Melted temp. $/{ }^{\circ} \mathrm{C}$ & $\mathrm{N}_{2}$ gas processing & $\mathrm{CN}^{-} /$Dross $/ \mu \mathrm{g} \mathrm{g}^{-1}$ \\
\hline 1 & Al-Si-Mg & 710 & Yes & 0.4 \\
\hline 2 & $\mathrm{Al}-\mathrm{Si}-\mathrm{Cu}$ & $650 \sim 670$ & Yes & 2.3 \\
\hline 3 & $\mathrm{Al}-\mathrm{Si}-\mathrm{Cu}$ & 780 & Yes & 2.0 \\
\hline 4 & $\mathrm{Al}-\mathrm{Cu}-\mathrm{Si}$ & $700 \sim 720$ & None & 0.4 \\
\hline 5 & $\mathrm{Al}-\mathrm{Cu}-\mathrm{Si}$ & $700 \sim 720$ & Yes & 2.1 \\
\hline 6 & $\mathrm{Al}-\mathrm{Si}-\mathrm{Mg}$ & $700 \sim 720$ & None & 0.7 \\
\hline 7 & $\mathrm{Al}-\mathrm{Si}-\mathrm{Mg}$ & $700 \sim 720$ & Yes & 0.3 \\
\hline 8 & $\mathrm{Al}-\mathrm{Mg}$ & $700 \sim 730$ & None & 0.7 \\
\hline 9 & $\mathrm{Al}-\mathrm{Si}-\mathrm{Mg}$ & $700 \sim 750$ & Yes & 4.5 \\
\hline 10 & Al-Si-Cu-Mg & $740 \sim 770$ & Yes & 6.3 \\
\hline 11 & Al-Si-Cu-Mg & $740 \sim 770$ & None & 0.9 \\
\hline
\end{tabular}

調べた。

廃棄物はふるい（メッシュ No14, $1.19 \mathrm{~mm}$ ) で分け, こ の試料 $30 \mathrm{~g}$ を $500 \mathrm{~mL}$ の分液漏斗に採取し, 水 $300 \mathrm{~mL}$ 加えて振とう機で 1 時間振とうし, 溶出した。 これを沪過 し, 沪液中の $\mathrm{CN}^{-}$をピリジン-ピラゾロン法で定量した. 沪 液中の $\mathrm{CN}^{-}$濃度から廃棄物（ドロス）中の $\mathrm{CN}^{-}$の溶出量 を求めた.アルミニウム合金溶融処理工場での原料, 処理 条件及び廃棄物中の $\mathrm{CN}^{-}$の溶出量を Table 10 に示す.

この結果, 廃棄物を水で溶出したすべての試料液から $\mathrm{CN}^{-}$が検出され, その溶出量は $0.3 \sim 6.33 \mu \mathrm{g} / \mathrm{g}$ であった. $\mathrm{CN}^{-}$の溶出量を比較すると, 窒素ガスを使用している炬か らの廃棄物中に $\mathrm{CN}^{-}$溶出量が多い傾向が認められた。

廃棄物からのシアンの検出原因は, 次のように推定され $3^{54)}$.

アルミニウム合金溶融廃棄物中には, 原料や添加物との 反応によってカルシウムやアルミニウムのカーバイドが含 まれていると考えられる.

また，アルミニウム合金の溶融中に窒素ガスを吹き込む と次の反応でカルシウムシアナミド及びアルミニウムシア ナミドを生成する.

$$
\begin{aligned}
& \mathrm{CaC}_{2}+\mathrm{N}_{2} \longrightarrow \mathrm{Ca}(\mathrm{CN})_{2} \longrightarrow \mathrm{CaCN}_{2}+\mathrm{C} \\
& \mathrm{Al}_{4} \mathrm{C}_{3}+6 \mathrm{~N}_{2}+9 \mathrm{C} \longrightarrow 4 \mathrm{Al}(\mathrm{CN})_{3}
\end{aligned}
$$

カルシウムシアナミド中の $\mathrm{CN}^{-}$の溶出率を確認するた めに, カルシウムシアナミドの一定量 $(0.15 \sim 3.0 \mathrm{~g})$ を採 取し，イオン交換水 $300 \mathrm{~mL}$ を加えて振とう機で 1 時間振 とうし, 溶出した。この溶出液を沪過した後, 汇液中の $\mathrm{CN}^{-}$を定量した結果, カルシウムシアナミド中の $\mathrm{CN}^{-}$の溶 出率は $0.017 〜 0.022 \%$ であった. したがって, アルミニウ ム合金溶融廃裹物からの $\mathrm{CN}^{-}$の検出原因は次のように推 定される.

アルミニウム合金及びフラックス中の金属が黒鉛るつほ あるいは六塩化エタン中の炭素と反応して金属カーバイド を生成する。これが空気中の窒素あるいは脱ガス処理のた
めの窒素と反応して金属シアナミドを生成し，加水分解に よって $\mathrm{CN}^{-}$が検出される.

4 全シアン分析方法の改正と前処理法の提案

\section{$4 \cdot 1 \mathrm{JIS}$ 法の全シアン分析の一部改正}

2 章で述べたように, JIS 法の全シアンの前処理における EDTA の添加効果については，その評価が分かれている.

添加した EDTA は難分解性のシアノ錯体から HCN を回 収する上で一定の効果はあるものの, EDTAを添加しなく ても, 亜鉛, 銅, カドミウム, ニッケル, 鉄のシアノ錯体 までは酸だけで分解すること ${ }^{27)}$ ，コバルトシアノ錯体のよ うな難分解性のシアノ錯体についてもリン酸を多量に加 え，シロップ状まで蒸留することにより分解することが明 らかになってきた ${ }^{23)}$. 更に, ペルオキソ二硫酸イオンと塩 化ヒドロキシルアンモニウムとの反応生成物 ${ }^{32)}$ (34), 硝酸 と亜鉛や鉄との反応生成物 ${ }^{35)}$ 及び重油 ${ }^{511}$, 軽質油 ${ }^{532}$, 石 炭 ${ }^{52)}$ の燃焼排ガスの洗浄液中に含まれる NS 化合物が加熱 蒸留中に EDTA と反応して HCN を生成する事例が明らか になってきたことから，EDTAを添加しなくてもよいので はないかとの報告が多くなってきた.

この結果， 2008 年 3 月に改正された JIS 法の注（8）で, 「EDTA が（HCN の生成に）関与すると考えられる場合に は, EDTA 溶液の添加を除いて1）から 7）の操作を行う.」 という事項が追記された2).

\section{$4 \cdot 2$ 全シアン前処理法の提案 ${ }^{28}{ }^{29}$}

シアンを含む試料から HCN を分離する方法として, JIS 法以外には, SM 法 $^{12)}$ と ISO 法 $^{13)}$ が用いられている. SM 法 では，塩化マグネシウムと硫酸を加えて加熱通気処理して $\mathrm{HCN}$ を水酸化ナトリウム（NaOH）溶液に捕集する．ISO 法では, 硫酸銅 (II) と塩化スズ (II), 塩酸を加えて加熱通 気処理して HCN を $\mathrm{NaOH}$ 溶液に捕集する. SM 法と ISO 法では, EDTAを添加しないので窒素酸化物が共存しても HCN が生成せず，しかも JIS 法の EDTA よりも金属シアノ 錯体からの全シアンの回収率は高い ${ }^{28}$. 一方, ISO 法の硫 


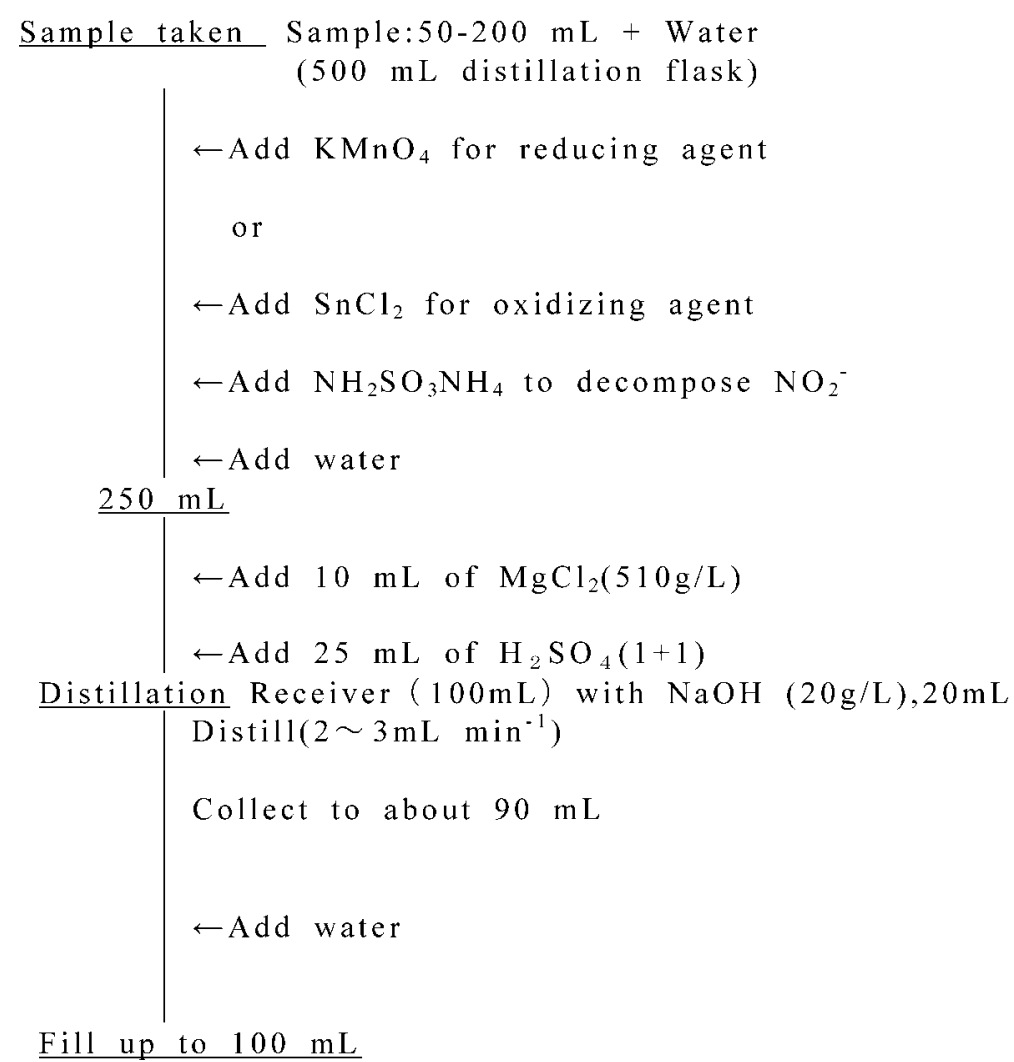

Fig. 2 Proposed distillation procedure of total cyanide ${ }^{28)}$

Table 11 Analytical results of total cyanide by the improved method ${ }^{28)}$

\begin{tabular}{|c|c|c|c|c|c|}
\hline Samples & Interferents & Red/Ox agents & \multicolumn{2}{|c|}{ Additives/g } & $\mathrm{CN}^{-}$found $/ \mathrm{mg} \mathrm{L}^{-1}$ \\
\hline A & $\begin{array}{l}\mathrm{NO}_{2}^{-} \\
\mathrm{NO}_{2}^{-}\end{array}$ & & $\begin{array}{l}\text { EDTA } \\
\mathrm{MgCl}_{2}\end{array}$ & $\begin{array}{l}1.0 \\
5.1\end{array}$ & $\begin{array}{l}1.8 \\
1.0\end{array}$ \\
\hline$A^{a)}$ & - & & $\begin{array}{l}\text { EDTA } \\
\mathrm{MgCl}_{2}\end{array}$ & $\begin{array}{l}1.0 \\
5.1\end{array}$ & $\begin{array}{l}1.0 \\
0.6\end{array}$ \\
\hline B & $\mathrm{S}_{2} \mathrm{O}_{8}{ }^{2-}+$ Organic comp. & $\mathrm{NH}_{3} \mathrm{OHCl}$ & $\begin{array}{l}\text { EDTA } \\
\mathrm{MgCl}_{2}\end{array}$ & $\begin{array}{l}1.0 \\
5.1\end{array}$ & $\begin{array}{l}4.0 \\
0.1\end{array}$ \\
\hline B & $\mathrm{S}_{2} \mathrm{O}_{8}{ }^{2-}+$ Organic comp. & $\mathrm{C}_{6} \mathrm{H}_{8} \mathrm{O}_{6}$ & $\begin{array}{l}\text { EDTA } \\
\mathrm{MgCl}_{2}\end{array}$ & $\begin{array}{l}1.0 \\
5.1\end{array}$ & $\begin{array}{l}0.1 \\
0.0\end{array}$ \\
\hline
\end{tabular}

A : Wastewater of metal heat treatment ; B : Wastewater of printed circuit board plating ;

a) Addition of ammonium amidosulfate to decompose $\mathrm{NO}_{2}$

酸銅と塩化スズ (II) を用いた場合は, 高濃度の銅の廃液が 出るので, 添加剤としては SM 法で定められている塩化マ グネシウムを用いることが推奨される.

シアンを含む試料から HCN を分離する操作を提案し, Fig. 2 に示す.

試料溶液中に還元剤が存在するときは，過マンガン酸カ リウムで酸化する。酸化剂が存在する場合は, 塩化ス ズ（II）で還元する．試料溶液中に亜硝酸イオンが存在する ときは, アミド硫酸アンモニウムを加えて分解する. 次に, $510 \mathrm{~g} / \mathrm{L}$ 塩化マグネシウム $10 \mathrm{~mL}$ 及び硫酸 $(1+1) 25 \mathrm{~mL}$ を加え, 加熱蒸留で HCN を分離し, $\mathrm{NaOH}$ 溶液に捕集す
る. 仮に加熱蒸留中にアミド硫酸アンモニウムで分解でき ない窒素酸化物が生成しても EDTAを添加していないの で，HCNの生成を防ぐことができる.

この方法で金属熱処理工場やプリント基板めっき工場な どの実排水を分析した結果を Table 11 に示す。この結果， 金属熱処理工場の排水（A）には亜硝酸イオンが含まれて いるが, $\mathrm{MgCl}_{2}$ を使用すると EDTAの場合よりも HCN の 生成量は減少した. この排水にアミド硫酸アンモニウムを 加えて亜硝酸イオンを分解すると, HCN の生成量は更に 減少した。 また，プリント基板めっき工場排水（B）の場 合は, 塩化ヒドロキシルアンモニウムで還元し, EDTAを 
添加して蒸留すると $4.0 \mathrm{mg} / \mathrm{L}$ の $\mathrm{CN}^{-}$が検出されたが, $\mathrm{MgCl}_{2}$ を添加して蒸留すると $0.1 \mathrm{mg} / \mathrm{L}$ に減少した. 更に, 塩化ヒドロキシルアンモニウムの代わりにアスコルビン酸 で還元すると, EDTA及び $\mathrm{MgCl}_{2}$ の場合もほとんど $\mathrm{HCN}$ が生成せず，良好に分析することができた ${ }^{28)}$.

また，この方法で重油燃焼排ガス洗浄液を分析した結 果, HCN は生成しなかったと報告している ${ }^{511}$. 更に, 久保 らは, 軽質油燃焼排ガス洗浄液中の全シアンをこの方法で 分析した結果，全シアンは検出されなかったと報告してい $3^{53)}$.

したがって，シアンを使用していない事業所等の排水か ら EDTAを添加することによって全シアンが検出された場 合には，この方法で確認してみるとよい.

\section{$4 \cdot 3$ 紫外線照射によるシアンから HCN の分離}

各種公定法（JIS，SM，ISO）で用いられている全シア ンの前処理は, 添加剤と酸を加え, 加熱蒸留して HCN を 分離する方法であるが，先に述べたように，加熱蒸留中に $\mathrm{HCN}$ を生成することがある。 また，試料に紫外線を照射し て，金属シアノ錯体から HCN を分離する方法も報告され て㧈り ${ }^{56) 57)}$, 酸添加, 加熱蒸留法に代わる新しい前処理法 として期待されている，著者らは，各種の金属シアノ錯体 を紫外線で分解してシアン酸イオン $\left(\mathrm{CNO}^{-}\right)$にした後, イオンクロマトグラフ法で定量する方法を開発してい $ろ^{58)}$.

\section{5 イオンクロマトグラフィーによるシアンの定量}

一般に酸解離定数 $\left(\mathrm{p} K_{\mathrm{a}}\right)$ が 7 以上の陰イオンや $\mathrm{CN}^{-}$ は, サプレッサーと電気伝導度を用いたイオンクロマトグ

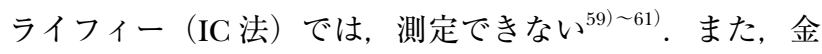
属シアノ錯体も解離しないため測定できない. しかし, $\mathrm{CNO}^{-}$の $\mathrm{p} K_{\mathrm{a}}$ は 3.66 であるから $\mathrm{CN}^{-}$を $\mathrm{CNO}^{-}$に酸化すれ ば，IC 法で測定することができる，そこで， $\mathrm{CN}^{-}$及び金属 シアノ錯体を次亜塩素酸ナトリウム $(\mathrm{NaClO})$ 溶液で酸 化した後，IC 法で定量する方法を開発した ${ }^{62) 633}$ 。この結 果, $\mathrm{CN}^{-}$及び覀鉛, カドミウム, 銅, 銀, ニッケルのシア ノ錯体からは $\mathrm{CNO}^{-}$が生成し， IC 法で定量できたが，鉄， 金, コバルトのシアノ錯体からは $\mathrm{CNO}^{-}$が生成せず， IC 法 で定量できなかった。 また, $\mathrm{NaClO}$ の代わりにクロラミン $\mathrm{T}$ 溶液で金属シアノ錯体を酸化した結果，同様に IC 法で定 量できることを明らかにした ${ }^{64)}$ 。この方法をめっき液中の 金属シアノ錯体の分析 ${ }^{65)}$ 及び各種シアン化合物の分析に応 用し ${ }^{66)}$, また, 環境水や水道水の低濃度のシアンの定量に も適用できることを報告した ${ }^{67)}$.

シアンを使用していないにもかかわらずシアンが検出さ れた場合には，全シアンの前処理で得られた留出液中の $\mathrm{CN}^{-}$を, JIS 法と測定原理の異なるこの IC 法で分析して確
認するとよい.

\section{6 ま ぬ め}

シアンは有毒物質であり，その排出は厳しく規制されて いることから，その濃度を正しく測定することが求められ ている。しかし，シアンを使用していない工場及び事業所 の排水や廃棄物からシアンが検出される事例が多数報告さ れ，行政機関とトラブルを生じている。

本稿では，全シアンを分析する時の問題点，シアンの生 成事例と生成原因について述べたが，シアン生成原因とし て, 排水中のシアンを安定に保つためのアルカリ固定や, 全シアンの前処理で添加する EDTA が HCN の生成に関与 することが明らかになった。

JIS 法で定められている全シアンの分析方法は, 本来シ アノ錯体や金属イオンを含む排水中の全シアンの測定を目 的として定められた方法であるが，この JIS 法は，シアン を含まない排水にも多用されていることから，加熱蒸留時 に排水中の亜硝酸イオンや窒素酸化物が添加した EDTA と の反応, 含窒素有機化合物の分解等によって, HCN を生成 することが明らかになってきた.

そこで，シアノ錯体と金属イオンを含み難分解性のシア ノ錯体を形成する排水の場合は, EDTA を添加して加熱蒸 留を行い, シアンを含まない排水の場合は, EDTAを添加 しないで加熱蒸留，あるいは，4·2 で提案した方法で $\mathrm{HCN}$ の分離を行うなど, 測定試料によって前処理法を分けるこ とも必要であると考える.

HCN は, 加熱蒸留のみならず, 室温に打いても化学反応 で簡単に生成することから，この現象はまさに「化学（バ ケガク)」であるといえる.

なお，「シアン化合物の分析と処理方法」として, シアン 化合物の特性と法規制 ${ }^{68)}$, 公定分析法 ${ }^{15)}$, 分析方法 ${ }^{11)}$, 分 離方法 ${ }^{69)}$, 簡易分析法 ${ }^{70)}$, 生成事例 ${ }^{6)}$, 生成反応 ${ }^{77}$, 環境污 染と防止対策 ${ }^{71}$, 処理方法 ${ }^{72773}$ や最近のシアン分析 ${ }^{74} に つ$ いての報告があるので参照されたい．

本研究に㧤いて，現場での調查やシアンの測定にご協力いただ いた多くの共同研究の皆様，また，この現象がまだあまり知られ ていなかった時に，いろいろなご教授を賜りました首都大学東京, 保母敏行名誉教授に感謝いたします。

\section{文献}

1) 水質污濁防止法：「人の健康に係る環境基準，昭和 45 年 4 月」, 「排水基準を定める総理府令, 昭和 46 年 6 月」.

2) JIS K 0102, 工場排水試験方法, p. 129 (2008).

3) 野々村誠：実務表面技術，32, 11 (1984).

4) 野々村誠：環境と測定技術， 17, 30 (1990).

5) 野々村誠: ぶんせき (Bunseki), 1994, 917.

6) 野々村誠: 工業用水, 494, 50 (1999).

7) 野々村誠: 工業用水, 495, 39 (1999).

8）小倉久子: 全国公害研会誌, 17, 7 (1992). 
9) 山田 悦, 長岡健二, 竹内豊英, 井勝久喜, 中川千 枝, 田中雅邦, 藤原 勇, 原由美子, 小島秀子, 坂 本隼雄, 後藤正志, 伊永隆史: 分析化学 (Bunseki Kagaku), 41, T103 (1992).

10) 野々村誠: 工業用水, 401, 12 (1992).

11) 野々村誠: 工業用水, 490, 39 (1999).

12) APHA : "Standard Methods for the Examination of Water and Wastewater 19th ed.”, p. 4-23 (1995) (American Public Health Association, Washington).

13) International Standard (Part1, ISO 6703/1, 1984, Determination of Total Cyanide) International Organization for Standardization.

14) 野々村誠: 工業用水, 349, 41 (1987).

15) 野々村誠: 工業用水, 489, 35 (1999).

16) JIS K 0102, 工場排水試験方法 (1964).

17) J. M. Kruse, M. G. Mellon : Anal. Chem., 25, 446 (1953).

18) JIS K 0102, 工場排水試験方法 (1971).

19) JIS K 0102, 工場排水試験方法 (1981).

20) JIS K 0102, 工場排水試験方法 (1986).

21) JIS K 0102, 工場排水試験方法 (1993).

22) JIS K 0102, 工場排水試験方法 (1998).

23) 中村栄子, 石井 進 : 工業用水, 457, 33 (1996).

24) 水上澄子：工業用水, 174, 41 (1973).

25）輿水敏子, 高松和幸, 阿相敏明, 金子幹宏, 西山信 一, 福井昭三, 菅野三郎：衛生化学, 20, 328 (1974).

26) 千葉県水質保全研究所資料 NO. 58 (環境庁委託業 務報告書)：シアン化合物分析方法の妨害物質等に 関する検討 (1992).

27) 小倉久子, 小熊幸一：水環境学会誌, $\mathbf{1 8}, 646$ (1995).

28) M. Nonomura : Intern. J. Environ. Anal. Chem., 35, 253 (1989).

29) 野々村誠：環境と測定技術, 17 (3), 36 (1990).

30) 輿水敏子, 高松和幸, 金子幹宏, 福井昭三, 菅野三 郎: 衛生化学, 20,332 (1974).

31）輿水敏子, 高松和幸, 金子幹宏, 福井昭三, 菅野三 郎: 衛生化学, 21, 1 (1975).

32) M. Nonomura: Toxicol. Environ. Chem., 17 (1), 47 (1988).

33) 野々村誠: 工業用水, 305, 26 (1984).

34) 並木 博, 中村栄子, 西田千寿, 小宮 聡, 大沢健 一, 酒井 将: 工業用水, 445, 9 (1995).

35) 小倉久子: 水環境学会誌, 17, 390 (1994).

36) 野々村誠：工業用水, 206, 35 (1975).

37) 野々村誠: 工業用水, 311, 26 (1984).

38) M. Nonomura, Y. Arakawa, K. Ootsuka, K. Kurita, H. Sugimori, Y. Kosaka: The $9^{\text {th }}$ Asian Conference on Analytical Science, p. 362 (2007).

39) 日本薬学会編 : “衛生試験法・注解”, p. 886 (2005).

40) M. Nonomura : Metal Fin., 92 (6), 21 (1994).
41) H. Tatsumoto, T. Hattori : Environ. Technol. Lett., 9, 1431 (1988).

42）山本真理，松崎淳三：千葉県水質保全研究所年報 (昭和 60 年度), p. 37 (1981).

43) 三好康彦, 嶋津輝之, 木村賢史 : 東京都環境科学研 究所年報, 1990 , p. 126.

44）野々村誠, 小林裕幸, 水澤伸也：日本写真学会誌, 52, 140 (1989).

45) M. Nonomura, F. Nakagawa, S. Mizusawa, T. Ohno, H. Kobayashi, T. Hobo: Intern. J. Environ. Anal. Chem., 39, 371 (1990).

46) 野々村誠：環境と测定技術， 20 (2), 36 (1993).

47) D. Owerbach : J. Water Pollut. Contr. Fed., 52, 2647 (1980).

48) 野々村誠: 工業用水, 410, 28 (1992).

49) M. Nonomura, M. Suzuki, T. Hobo, K. Dejima, H. Hotta : Toxicol. Environ. Chem., 39, 65 (1993).

50) H. Modler, M. Nonomura: Toxicol. Environ. Chem., 48, 155 (1995).

51）井村英明，山本鉄雄，勝原 豊，平島 佳 : 工業用 水, 565, 54 (2005).

52) 大山聖一, 佐藤一男: 電力中央研究所報告, V06501, (2006).

53) 久保暁子, 戸田英二：工業用水，591，66 (2008).

54) M. Nonomura, H. Ogino, T. Hobo : Aluminium, 65, 628 (1989).

55) 野々村誠：環境と測定技術， 20 (3), 20 (1993).

56) P. D. Goulden, B. K. Afghan, P. Brooksbank: Anal. Chem., 44, 1845 (1972).

57) Y. Liu, R. D. Rocklin, J. Joyle, M. J. Doyle : Anal. Chem., 62, 766 (1990).

58) 野々村誠, 高鴨雅則：工業用水, 469, 16 (1997).

59）及川紀久雄，今泉範子，野々村誠：ぶんせき (Bunseki), 1994, 111.

60) 野々村誠：ぶんせき (Bunseki), 1998, 856.

61) 野々村誠：ぶんせき (Bunseki), 2007, 192.

62) M. Nonomura: Anal. Chem., 59, 2073 (1987).

63) 野々村誠: 分析化学 (Bunseki Kagaku), 54, 191 (2005).

64) M. Nonomura, T. Hobo : J. Chromatogr., 465, 395 (1989).

65) M. Nonomura : Metal Fin., 85 (12), 15 (1987).

66) 野々村誠: 工業用水, 457, 45 (1996).

67) 野々村誠, 李 卉：日本分析化学会第 20 回イ才 ンクロマトグラフィー討論会, p. 86 (2003).

68) 野々村誠: 工業用水, 488, 8 (1999).

69) 野々村誠: 工業用水, 491, 42 (1999).

70) 野々村誠: 工業用水, 492, 51 (1999).

71) 野々村誠: 工業用水, 496, 24 (2000).

72) 野々村誠: 工業用水, 497, 22 (2000).

73) 野々村誠: 工業用水, 501, 16 (2000).

74) 小池 満 : 環境と測定技術, 34 (4), 87 (2008). 


\title{
Hydrogen Cyanide Formation on the Analysis of Total Cyanide and Free Cyanide and Improvements of Pretreatment Method of Total Cyanide
}

\author{
Makoto NONOMURA ${ }^{1,2}$ \\ ${ }^{1}$ Evaluation Research Institute of Environmental Technology, 2954-1-107, Togasaki, Misato-shi, Saitama \\ 341-0044 \\ ${ }^{2}$ Tokyo Metropolitan Industrial Technology Research Institute Development \& Research Department, 3-13-10, \\ Nishigaoka, Kita-ku, Tokyo 115-8586
}

(Received 2 June 2008, Accepted 7 January 2009)

The total cyanide contents in the environment and wastewater are strictly regulated, because cyanide compounds are very toxic substances. Generally, total cyanide is determined by the JIS method in Japan. However, many reports have been issued that cyanide ion had been detected in wastewater and waste discharged from factories that do not handle any cyanide compounds. These examples included printed circuit board plating, non-cyanide zinc plating, photographic processing waste solutions, electro-deposited paints, aluminum processing waste, etc.. It was theorized that hydrogen cyanide was formed by the reaction of organic compounds, such as EDTA and nitrogen oxides, during the distillation process or under high-temperature conditions. Recently, free cyanide ion was detected in an electro-less nickel plating bath at room temperature by alkaline fixation. The total cyanide was detected in an absorbed solution of the heavy oil combustion gas and in the effluent of a coal-fired station. This paper describes the cause of cyanide formation based on these examples. In addition, a pretreatment method of total cyanide by JIS was improved, and a new separation procedure for the total cyanide was proposed.

Keywords : wastewater ; cyanide formation ; total cyanide ; free cyanide ; distillation ; alkaline fixation. 